\title{
A comparative analysis of selected wastewater pretreatment processes in food industry
}

\author{
Katarzyna Jaszczyszyn ${ }^{1, *}$, Wojciech Góra ${ }^{1}$, Zbystaw Dymaczewski ${ }^{1}$, and Robert Borowiak ${ }^{1}$ \\ ${ }^{1}$ Faculty of Civil and Environmental Engineering, Poznan University of Technology, 5 Piotrowo, \\ 60-965 Poznan, Poland
}

\begin{abstract}
The article presents a comparative analysis of the classical coagulation with the iron sulphate and adsorption on bentonite for the pretreatment of wastewater in the food industry. As a result of the studies, chemical oxygen demand (COD) and total nitrogen (TN) reduction were found to be comparable in both technologies, and a $29 \%$ higher total phosphorus removal efficiency by the coagulation was observed. After the coagulation and adsorption processes, a significant difference between mineral and organic fraction in the sludge was found $(49 \%$ and $51 \%$ for bentonite and $28 \%$ and $72 \%$ for iron sulphate, respectively).
\end{abstract}

\section{Introduction}

Industrial pollution are a large and various group of contaminants. According to the NACE Rev. 2 - Statistical classification of economic activities in the European Community and in Poland - Polish Classification of Activities [1-2], in the Classification scheme, food industry is included in the Section $\mathrm{C}-$ Manufacturing. The section named: Manufacture of food products and Manufacture of beverages contains two categories of food industry. The first is: processing of products from agriculture, forestry, hunting and fishing in the food and drink for humans or animals and activities which result in a variety of products, such as: meat, fish, fruit and vegetables, fats and oils, dairy products, grain mill products, pet food, other groceries. And the second one contains: production of soft drinks, mineral water, alcohol, beer and wine. Poland is one of the largest agri-food industry producer in Europe [3]. In 2013 in Poland the share of sold production of the agri-food industry in the sold production of the entire processing industry exceed 22\%, it is about PLN 215.7 billion, EUR 51.48 billion [4].

In Poland, the largest share in the wastewater production (over 85\%) comes from electricity, gas, steam and hot water supply and about $9.4 \%$ from manufacturing. Wastewater from manufacturing of food products and of beverages in the total amount of industrial wastewater is about $1.2 \%$, and in the Section $\mathrm{C}$ - Manufacturing it contains, about $12.1 \%$ [5]

In industries water is used for different purposes - during the production process, washing, diluting, cooling and other. Compared to other industries sectors, the food industry uses a relatively large amount of water per unit of product. The consumption of

* Corresponding author: katarzyna.jaszczyszyn@put.poznan.pl 
water in the food industry is related to the required high quality of the product and hygienic considerations.

One of the major consumers (24\%) of freshwater among food and beverage processing facilities on the global market is the meat processing industry [6]. Typical water usage in this industry is about 1.5 to even $60 \mathrm{~m}^{3} /$ ton of product [7-8].

Wastewater in the food industry generally contain high concentration of organic pollutant. These are, above all, macromolecular protein complexes, carbohydrates, fats and parts of fruits/vegetables, bones etc. [9-11]. Wastewater from meat industry contain high concentration of suspended solids, including pieces or fat, feathers, flesh, manure or undigested feed $[10,12]$. Blood as one of the major dissolved pollutants in slaughterhouse wastewater has high chemical $(\mathrm{COD})$ and biological $\left(\mathrm{BOD}_{5}\right)$ oxygen demand. Meat industry wastewater is very harmful to the environment. Effluent discharge from slaughterhouse has caused deoxygenation of rivers and contamination of groundwater [12].

Table 1. General characteristics of selected industrial wastewater [6, 10-11, 13-14].

\begin{tabular}{|c|c|c|c|}
\hline \multicolumn{2}{|l|}{} & Slaughterhouse & Bakery \\
\hline $\mathrm{COD}$ & $\mathrm{mg} / \mathrm{L}$ & $500-15900$ & $1.5-18 \mathrm{~kg} /$ tonne \\
\hline $\mathrm{BOD}_{5}$ & $\mathrm{mg} / \mathrm{L}$ & $150-4635$ & $155-8500$ \\
\hline $\mathrm{TN}$ & $\mathrm{mg} / \mathrm{L}$ & $50-841$ & $\mathrm{~N} / \mathrm{D}^{*}$ \\
\hline $\mathrm{TP}$ & $\mathrm{mg} / \mathrm{L}$ & $25-200$ & $\mathrm{~N} / \mathrm{D}$ \\
\hline $\mathrm{TSS}$ & $\mathrm{mg} / \mathrm{L}$ & $270-6400$ & $130-5700(13430)$ \\
\hline Fats/grease & $\mathrm{mg} / \mathrm{L}$ & $160-2500$ & $60-1200(4490)$ \\
\hline $\mathrm{pH}$ & - & $4.9-8.1$ & $4.7-8.4$ \\
\hline *N/D-no data. $^{2}$ & &
\end{tabular}

The bakery industry is another example of the food industry with a high water consumption, which is about $9 \%$ of freshwater consumption in beverage and food industries [6]. More than a half of the water in bakery plants is discharged as wastewater. Wastewater is primarily generated from cleaning operations including equipment cleaning and floor washing. It may contain flour, sugar, salt, yeast, water, and oil/fat. During the manufacturing processes, hot water mixed with detergents is used in Cleaning-In-Place systems [13].

The different types of industrial wastewater contamination requirements causes a variety of strategies for treatment technologies. About $65-90 \%$ of the organic matter in food industry wastewater is colloidal or particulate and it can be reduced to a high degree by the chemical pretreatment of raw wastewater [15]. Most of the solids can be removed using simple sedimentation techniques with the solids recovery as slurry or sludge. However, classical pretreatment methods for industrial wastewater which based on mechanical and physical-chemical processes, are often insufficiently effective, and also waste streams are difficult to manage. Coagulation process using inorganic coagulants may result in the production of huge volume of sludge and aluminium or iron salts that may be retained in the treated water [16]. According to that, new and highly effective pretreatment methods that will take into account the residual pollutions as well as an impact of applied processes on the sludge management, are being developed [17-18]. An exemplary method that meets the current criteria is an adsorption with mineral sorbents application combined with flocculation [19]. 
Clay minerals show outstanding adsorption properties for numerous organic products [20-22].

This paper presents a comparative research results of two different wastewater pretreatment methods in three industrial plants - meat (IP1, IP2) and bakery industry (IP3).

\section{Materials and methods}

Averaged wastewater samples from three industrial plants (IP): slaughter and meat processing (IP1 and IP2) and bakery industry (IP3) were analysed. The choice of the industrial plant type was followed by, among others, the ease of their collection with technical equipment and the diversity in the composition of pollution.

All of the samples for analysis were taken from the wastewater treatment line of each plant as averaged and raw wastewater. Pretreatment processes with iron sulphate and natural Na-bentonite, as a mineral sorbent, were carried out.

The natural bentonite samples used for the experiments was obtained from Hekobentonity Ltd., Poland. Bentonite was applied as a 5\% water suspension.

The specific surface area of bentonite was determined by the nitrogen adsorptiondesorption method at $77 \mathrm{~K}$ on ASAP 2420 analyser. BET surface area for the bentonite was $58.517 \mathrm{~m}^{2} / \mathrm{g}$. Elemental composition of raw bentonite was analysed by SEM equipped with EDS detector (QUANTA $250 \mathrm{FEG}, \mathrm{FEI}$ ). Bentonite chemical composition (in \%): $\mathrm{Na}_{2} \mathrm{O}-$ 3.60, $\mathrm{MgO}-2.41, \mathrm{Al}_{2} \mathrm{O}_{3}-24.92, \mathrm{SiO}_{2}-63.49, \mathrm{~K}_{2} \mathrm{O}-0.69, \mathrm{CaO}-1.65, \mathrm{Fe}_{2} \mathrm{O}_{3}-3.24$.

The iron sulphate coagulant $\left(\mathrm{Fe}_{2}\left(\mathrm{SO}_{4}\right)_{3}\right)$ was obtained from Kemipol Ltd., Poland. Polyelectrolytes were delivered by Korona JV., Poland. Hydrochloric acid 0,1M (Chempur, Poland) and sodium hydroxide $0,1 \mathrm{M}$ (Chempur, Poland) were used for the $\mathrm{pH}$ adjustment.

All chemicals were of analytical grade and used as received. In the experiments, distilled water was used for all experiments to preparing the solutions and suspensions.

Batch experiments was conducted in laboratory conditions in $1 \mathrm{dm}^{3}$ reactors using a Kemira Flocculator equipped with 6 glass beakers connected to a tachometer controlled stirrers. Kemira Flocculator allows to control both processes coagulation and flocculation. Depending on the specifics of the process, a different process time was programmed for quick mixing, slow mixing, and sedimentation. Mixing times and speeds have been selected to illustrate the processes that take place on a technical scale in a classical coagulation and flocculation system.

The turbidity measurement was performed on the Turb 350IR nephelometer, WTW.

The tests were performed in triplicate for each test to obtain a more reliable result.

The scope of physical-chemical analysis included determining the basic parameters of raw and purified (pre-treated) wastewater (COD, total nitrogen and total phosphorus concentration and dry matter in the obtained sediment).

All chemical analysis of wastewater and sludge were conducted in accordance with the applicable standards and standard methods. COD analysis was prepared with ISO 15705:2002 - Determination of the chemical oxygen demand index (ST-COD).

Determination of dry matter and water content on a mass basis in sediment and sludge was also conducted. For this purpose, the dry weight of the sludge was tested after drying in drying oven thermostatically controlled with forced air ventilation, maintaining a temperature of $(105 \pm 5)^{\circ} \mathrm{C}$.

The sludge was subjected to a drying process in accordance with the guidelines in EN 12880: 2004 - Determination of dry residue and water content. As the final result, the average of three samples was taken. The same crucibles were used for the subsequent loss on ignition measurement, ignited at $550^{\circ} \mathrm{C}$ in the muffle furnace. 


\section{Experimental results}

Initially, concentration of chemical oxygen demand (COD), total nitrogen (TN) and total phosphorus (TP) in untreated wastewater samples from three industrial plants (IP1, IP2, IP3) were investigated. The results are compiled in Table 2.

Table 2. Untreated (daily averaged) wastewater samples characterization.

\begin{tabular}{|c|c|c|c|c|}
\hline \multicolumn{2}{|c|}{} & \multicolumn{3}{|c|}{ Sample ID } \\
\cline { 3 - 5 } & & IP1 & IP2 & IP3 \\
\hline $\mathrm{COD}$ & $\mathrm{mg} / \mathrm{L}$ & $2960 \pm 62.2$ & $4730 \pm 125.3$ & $9530 \pm 357.6$ \\
\hline $\mathrm{TN}$ & $\mathrm{mg} / \mathrm{L}$ & $228 \pm 6.9$ & $206 \pm 5.3$ & $66.5 \pm 4.5$ \\
\hline $\mathrm{TP}$ & $\mathrm{mg} / \mathrm{L}$ & $25.6 \pm 0.8$ & $28.8 \pm 1.3$ & $12.8 \pm 1.0$ \\
\hline
\end{tabular}

IP1, IP2 - slaughter and meat processing, IP3 - bakery industry.

On the basis of preliminary research, the flocculant that works best with the given coagulant on a given wastewater test was selected to further analysis.

The first stage of the research was coagulant dose selection. There were carried out six series in every stage of the research. Dosages in the range of $0.15-1.2 \mathrm{~g} / \mathrm{L}$ for iron sulphate and $0.3-1.8 \mathrm{~g} / \mathrm{L}$ for bentonite were tested.

The final dosage of the reagents was determined on the basis of the turbidity of the supernatant liquid.

As the best dose, it was found the smallest turbidity of the supernatant liquid. Fig. 1. and Fig. 2. illustrate the experimental results of the coagulant dosage selection.

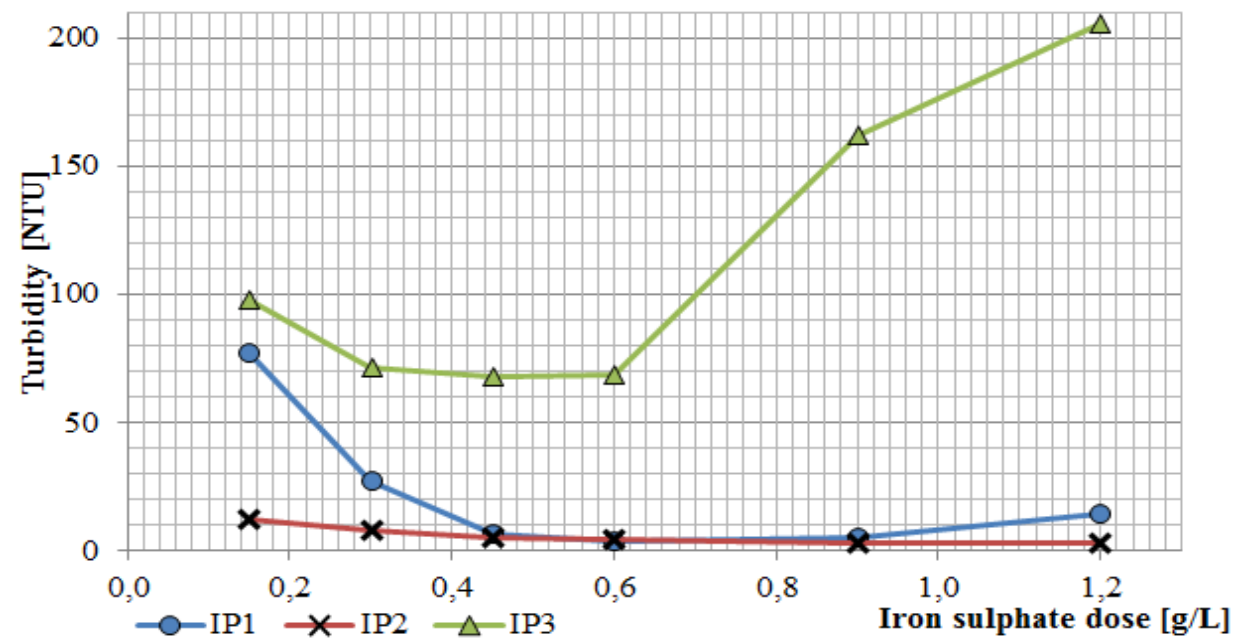

Fig. 1. Influence of doses of iron sulphate on wastewater turbidity. 


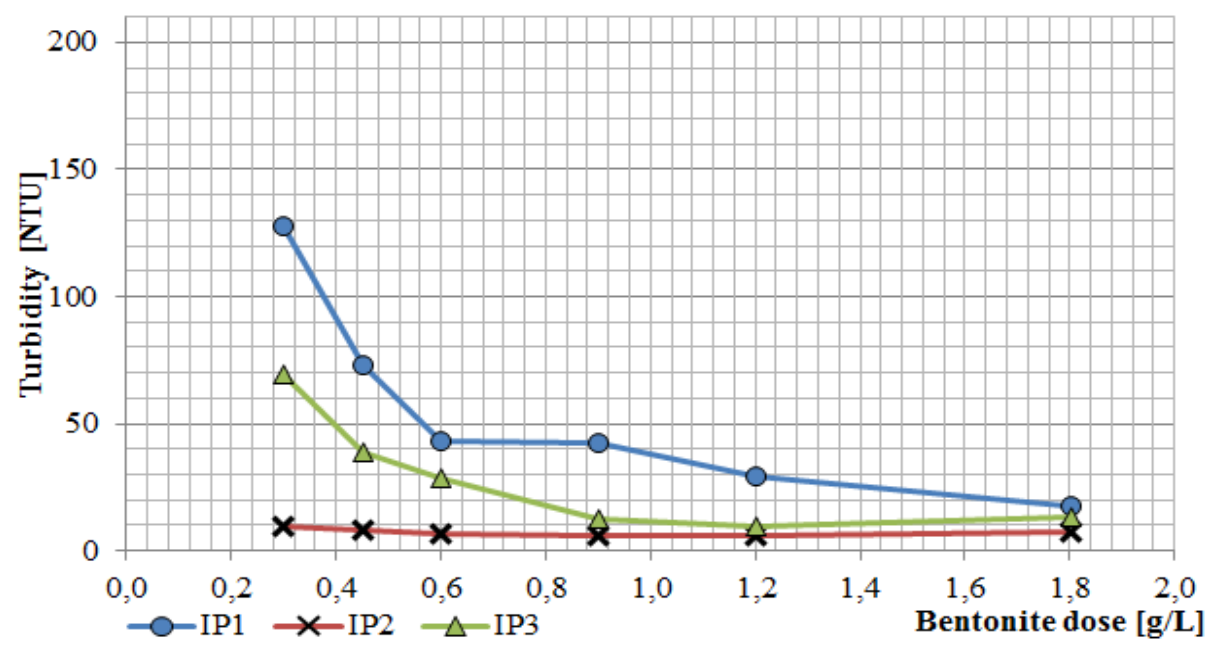

Fig. 2. Influence of doses of bentonite on wastewater turbidity.

Reagent doses selected to the further researches: iron sulphate IP1 $-0.6 \mathrm{~g} / \mathrm{L}, \mathrm{IP} 2-$ $0.9 \mathrm{~g} / \mathrm{L}, \mathrm{IP} 3-0.45 \mathrm{~g} / \mathrm{L}$ and for bentonite IP1 $-1.8 \mathrm{~g} / \mathrm{L}, \mathrm{IP} 2-0.9 \mathrm{~g} / \mathrm{L}, \mathrm{IP} 3-0.9 \mathrm{~g} / \mathrm{L}$.

For selected reagent doses pre-treated wastewater samples and obtained sediments have been analysed. The effectiveness results of the COD, Nitrogen and Phosphorus reduction are compiled in Table 3. Effectiveness of the reduction of selected pollutants are also shown in the Fig. 3.

Table 3. Effectiveness of the reduction of selected pollutants.

\begin{tabular}{|c|c|c|c|c|c|c|c|}
\hline \multicolumn{2}{|c|}{} & \multicolumn{3}{|c|}{ Bentonite } & \multicolumn{3}{c|}{ Iron sulphate } \\
\cline { 3 - 8 } & IP1 & IP2 & IP3 & IP1 & IP2 & IP3 \\
\hline COD & $\%$ & 84.4 & 84.7 & 71.0 & 93.4 & 95.3 & 79.4 \\
\hline TN & $\%$ & 83.1 & 77.4 & 82.7 & 90.0 & 72.1 & 88.0 \\
\hline TP & $\%$ & 53.9 & 69.4 & 82.8 & 98.4 & 98.6 & 96.9 \\
\hline
\end{tabular}

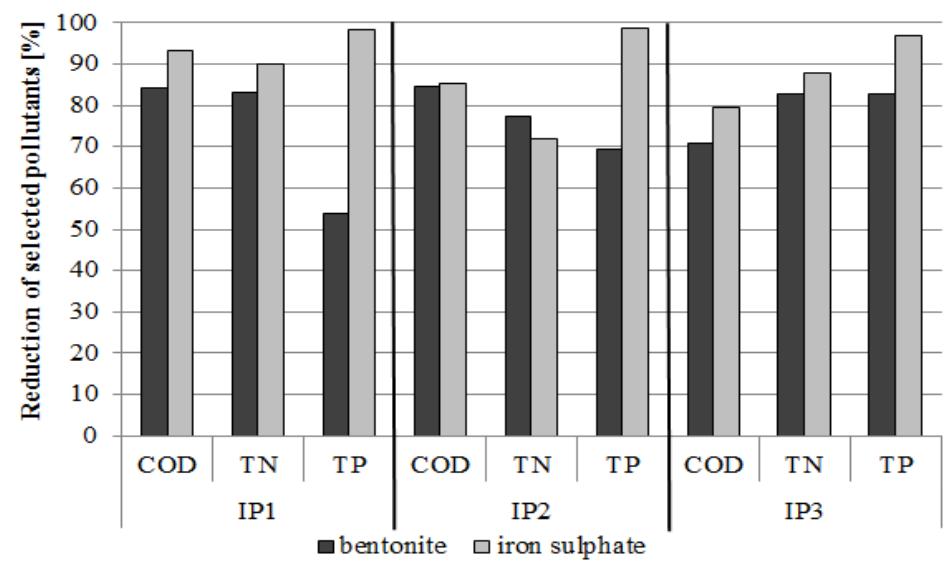

Fig. 3. Effectiveness of the reduction of COD, total nitrogen and total phosphorus [\%] 
Percentage content of the fixed solids and volatile solids contained in the sediments are compiled in Table 4. and shown in the Fig. 4.

Table 4. Percent of dry matter content in the sediment sludge.

$(\mathrm{FS}-$ fixed solids $=$ mineral matter fraction, $\mathrm{VS}-$ volatile solids $=$ organic fraction $)$

\begin{tabular}{|c|c|c|c|c|c|c|c|}
\hline \multicolumn{2}{|c|}{} & \multicolumn{3}{|c|}{ Bentonite } & \multicolumn{3}{c|}{ Iron sulphate } \\
\cline { 2 - 8 } & IP1 & IP2 & IP3 & IP1 & IP2 & IP3 \\
\hline FS & $\%$ & 63.0 & 39.7 & 44.3 & 23.9 & 27.9 & 25.0 \\
\hline VS & $\%$ & 37.0 & 60.3 & 55.7 & 76.1 & 72.1 & 75.0 \\
\hline
\end{tabular}

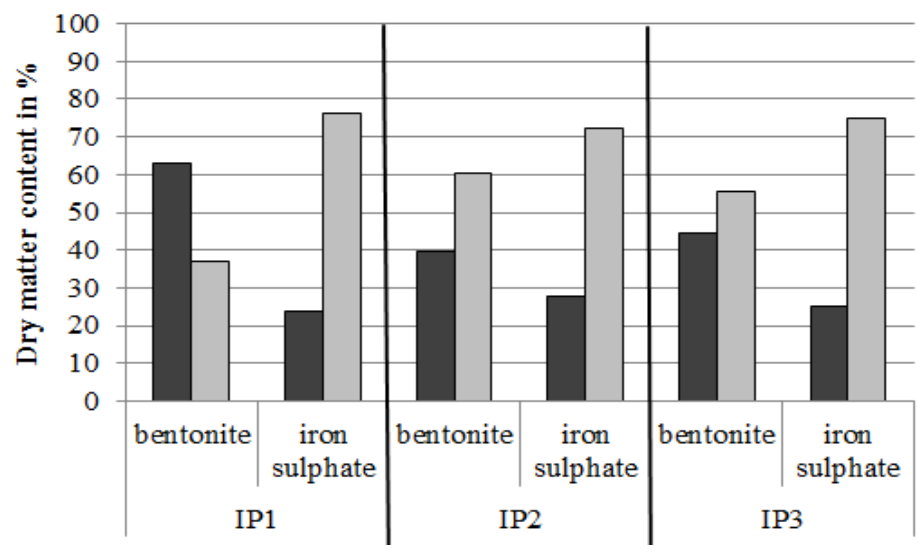

a F - fixed solids

口VS - volatile solids

Fig. 4. Dry matter content (in\%) in the sediment sludge after pretreatment.

\section{Discussion}

Initially, concentration of chemical oxygen demand (COD), total nitrogen (TN) and total phosphorus (TP) in daily averaged untreated wastewater samples from three industrial plants (IP1, IP2, IP3) were investigated. The results are compiled in Table 2.

Similar concentrations of total nitrogen and total phosphorus were found in wastewater samples from plants IP1 (slaughter) and IP2 (meat processing). COD was higher in the sample of wastewater from the meat processing plant (about $60 \%$ ).

Wastewater from meat industry is suitable for biological treatment [7]. For IP1 and IP2 the ratio of $\mathrm{C}: \mathrm{N}: \mathrm{P}$ is 100: 7.7: 0.9 and 100: 4.4: 0.6 respectively, which nearly ensures the balance of carbon compounds and nutrients for biological processes in untreated wastewater. In the case of IP3 sample (from bakery), COD value was more than twice as high as in the meat industry samples, while significantly lower concentrations of both total nitrogen and total phosphorus, which is typically for the bakery industry (see Table 1.). The ratio of $\mathrm{C}$ : $\mathrm{N}$ : $\mathrm{P}$ in the wastewater sample from the bakery (IP3) is 100: 0.7: 0.1 and is not balanced for biological treatment. In the case of biological treatment using following pretreatment processes, it is appropriate to proportional reduce the concentration of pollutants from the meat industry plants (IP1, IP2) and to maximize the reduction of COD in the case of wastewater from the bakery (IP3).

In the pretreatment process of wastewater from meat industry (IP1 and IP2) with iron sulphate as a coagulant, the efficiency of total phosphorus removal was $98-99 \%$. Similar results were obtained by some authors with application of other coagulants - polyaluminum 
chloride or alum as the reagent - 99.9 and 98\% TP removal, respisevely [6]. By using alum, ferric chloride and ferric sulfate Amuda and Alade achieved significantly lower efficiency: 45, 32 and 39\% TP removal, respectively [23].

Other hand, by application of the bentonite the efficiency of TP removal for IP1 and IP2 was 54 and $\sim 70 \%$. In wastewater from bakery industry (IP3), the total phosphorus removal efficiency was $97 \%$ with iron sulphate, while with bentonite $\sim 83 \%$.

For all investigated wastewater samples, a lower total phosphorus removal efficiency was obtained by the use of bentonite. This is most likely related to the chemical precipitation of orthophosphates using iron sulphate [24].

The use of bentonite may be beneficial to preserve the increased phosphorus content after pretreatment processes to balance the composition of effluent for the biological processes as an appropriate treatment degree.

For all samples, total nitrogen removal using both agents: iron sulphate and bentonite has yielded comparable efficacy, and on average $83 \%$ and $81 \%$, respectively. The COD reduction was most affected by the use of iron coagulant - $79-93 \%$, and $71-85 \%$ for bentonite.

From the values obtained during the determination of dry matter content and dry residue, the largest share of organic matter content was obtained by using iron coagulant (above $70 \%$ for each type of industry). The content of organic matter in the bentonitetreated sediment was varied and oscillate between $37 \%$ and $60.3 \%$.

The high content of mineral fraction in the sediments after pretreatment with bentonite affects the potential methods of its management. Considering the iron content in natural bentonite $\left(\mathrm{Fe}_{2} \mathrm{O}_{3}-3.24 \%\right)$ and the iron content in the coagulant - $\mathrm{Fe}_{2}\left(\mathrm{SO}_{4}\right)_{3}$, it is expected to considerably lower iron content in the sediment sludge after bentonite application. This fact may also be important for some sediment management methods.

\section{Summary}

For both methods - iron sulphate coagulation as well as adsorption with bentonite, comparable COD and total nitrogen removal efficiencies were obtained (the slightly better results were obtained for the COD removal using iron sulphate). In the coagulation, the efficiency of phosphorus removal was $29 \%$ higher than in the adsorption. Other hand, in the adsorption process, about a $20 \%$ higher of the mineral matter content in the sludge was achieved.

Application of bentonites for the pretreatment of food processing industry, may be an alternative method to the classical coagulation process.

Analysing the directions of sludge management, depending on the applied pretreatment technology, significant differences in sediment composition obtained in both methods should be taken into account.

\section{References}

1. Central Statistical Office of Poland, Polish Classification of Activities PKD; in Polish (2007)

2. Eurostat, N.A.C.E. Rev.2. (Office for Official Publications of the European Communities, Luxemburg, 2008)

3. Global Agricultural Information Network, Food Processing Sector Report (Warsaw, 2016)

4. Polish Information and Foreign Investment Agency, Food sector in Poland (Economic Information Department, 2015) 
5. Central Statistical Office of Poland, Statistical Yearbook of Industry 2016 (Warsaw, 2017)

6. C.F. Bustillo-Lecompte, M. Mehrvar, J Environ Manage 161 (2015)

7. World Bank Group, Meat processing and rendering. Project Guidelines: Industry Sector Guidelines, in: Pollution Prevention and Abatement Handbook (1998)

8. A. Steinhoff-Wrześniewska, A. Rajmund, J. Gwozdoń, Inżynieria Ekologiczna 32; in Polish (2013)

9. F. Meinck, H. Stoff, H. Kohlschuter, Ścieki przemystowe (Arkady, Warsaw, 1975), Polish translation of: F. Meinck, H. Stoof, H. Kohlschütter, Industrieabwasser (1968)

10. H. Rüffer, K.H. Rosenwinkel, Oczyszczanie ścieków przemystowych: Poradnik. (Oficyna Wydawnicza Projprzem-Eko, 1998), Polish translation of: K.H. Rosenwinkel, Taschenbuch der Industrieabwasserreinigung (Oldenbourg, 1991)

11. C.J. Banks, Z. Wang, Treatment of meat wastes. In: Waste Treatment in the Food Processing Industry, in: L. K. Wang, Z. T. Hung, H. H. Lo, C. Yapijakis, Waste treatment in the food processing industry (Taylor \& Francis Group, Florida, 2006)

12. D.I. Massé, L. Masse, Canadian Agricultural Engineering 42, 3 (2000)

13. J.P. Chen, L. Yang, R. Bai, Y.T. Hung, Bakery Waste Treatment, in: L.K. Wang, Y.T. Hung, H.H. Lo, C. Yapijakis, Waste treatment in the food processing industry (Taylor \& Francis Group, Florida, 2006)

14. B. Bartkiewicz, K. Umiejewska, Oczyszczanie ścieków przemystowych; in Polish (Wydawnictwo Naukowe PWN, 2010)

15. M.H. Sorour, A.G. Aboulnour, A.A. Mostafa, H.F. Shaalan, M.H. El-Sayed, and H.A. Hani, World Applied Sciences Journal 26, 8 (2013)

16. T. Kazi, A. Virupakshi, IJIRSET 2, 8 (2013)

17. Ministry of the Environment, Najlepsze dostepne techniki BAT - wytyczne dla branży spożywczej: owocowo-warzywnej (soki i nektary, przetwory, mrożonki; in Polish (ENVIRON Poland Sp. z o.o., Warsaw, 2004)

18. A.P. Vanerkar, S. Satyanaryan, S. Satyanaryan, IJCPS 2, Special Issue (2013)

19. E. Worch, Adsorption technology in water treatment: fundamentals, processes, and modelling (de Gruyter, Berlin/Boston, 2012)

20. Z. Lizhong, Z. Jianying, L. Yimin, S. Xueyou, Q. Wenbin, Journal of Environmental Sciences 8, 3 (1996)

21. J. Kaleta, D. Papciak, A. Puszkarewicz, Rocznik Ochrona Srodowiska 15, 3; in Polish (2013)

22. T.P.A. Shabeer, A. Saha, V.T. Gajbhiye, S. Gupta, K.M. Manjaiah, E. Varghese, Environ Technol. 35 (2014)

23. O.S. Amuda, A. Alade, Desalination 196.1 (2006)

24. E. Nassef, ESTIJ 2, 3 (2012) 